\title{
Regeneration Standards: What has the past to show us? 1
}

\author{
by K.A. Armson²
}

\begin{abstract}
The historical development of regeneration surveys in Canada and the associated development of methodologies and standards are reviewed. The importance of sampling methodology and quadrat size in determining stocking values is stressed. The use of technically-based stocking data to inform the public about regeneration is questioned. It is argued that there is need for a new and imaginative measure that is both factual and can be readily comprehended by the public. This presents a challenge to foresters and the governments when reporting on the state of the public's forests.
\end{abstract}

Key words: regeneration standards, stocking, quadrat size, survey methodology, terminology and presentation

\section{RÉSUMÉ}

Cet article passe en revue l'historique du développement des inventaires de régénération au Canada et de l'élaboration des méthodologies et des normes qui y sont associées. L'importance de la méthodologie d'échantillonnage et de la taille du quadrant pour ce qui est de l'évaluation de la valeur des semis est mise en évidence. L'utilisation de données techniques sur les semis pour informer le public sur l'état de la régénération est remise en question. On invoque qu'il est nécessaire d'avoir une nouvelle mesure représentative qui soit à la fois descriptive et qui puisse être facilement comprise par le public. Ceci constitue un défi pour les forestiers et les gouvernements lorsqu'il est question de faire rapport sur l'état des forêts publiques.

Mots clés : normes de régénération, nombres de semis, taille du quadrant, méthodologie d'inventaire, terminologie et présentation

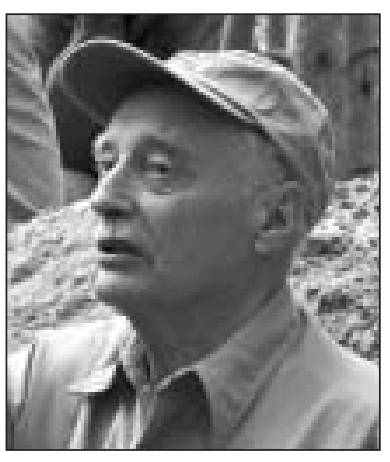

K.A. Armson
Forest regeneration standards are largely a North American and particularly Canadian concern - in some quarters I might even say an obsession. European foresters in the late $19^{\text {th }}$ and early $20^{\text {th }}$ centuries assumed regeneration was an integral part of their forest management as exemplified in the formal systems of silviculture they employed. Sir William Schlich in volumes II and III, silviculture and forest management, respectively, of his five-volume Manual of Forestry (Schlich 1906) makes no mention of regeneration standards or need for them. It is implicit that the forester will ensure the regeneration necessary to meet the objectives for which each forest is being managed.

Fernow in 1902 stated, “... the main business of the forester is expressed in one word reproduction; his main obligation is the replacement of the crop he has harvested..." This emphasis by Fernow reflected the situation in North America where natural forests were being exploited and harvested or burned without any semblance of management and therefore no systematic application of silvicultural systems with their concomitant obligatory regeneration. In Canada, as in the United States, the latter decade of the $19^{\text {th }}$ and the first decades of the $20^{\text {th }}$ centuries were marked by a major concern of some lumbermen, senior government officials and a few politicians about the future state of Canada's forests. In Canada, the first organized attempts to document the state of the forests following logging came federally from the Commission on Conservation under Clifford Sifton. The earliest surveys were not so much regeneration surveys as we now know them but rather surveys limited in scale and intensity to determine the nature of the forests; though they focused on logged-over and burned-over lands. For example, the Trent Watershed Survey of 1912 (Howe and White 1913) was conducted because the Dominion Government had spent some 10 million dollars on building a canal and there was concern whether the extent of logging and fires in the watershed would seriously jeopardize the water flow necessary to maintain the canal system. The Forest Conditions of Nova Scotia (Fernow et al. 1912) was a broad reconnaissance survey but concluded that one quarter of the present forest area of the province was "semi-barren of commercial trees." The work of the Commission was taken over by the Dominion Forest Service, but it was not until the end of World War I that any significant attempt to conduct regeneration surveys occurred. This reflected three factors:

1. The need to determine the nature of forest conditions. This was driven by such persons as Fernow from the academic and professional side but it also received substantive political support.

2. The increasing availability of young professional foresters from the recently established faculties of forestry at

\footnotetext{
${ }^{1}$ Presentation to the Interprovincial Meeting on Forest Renewal Standards and Silviculture Effectiveness Monitoring, Toronto, February 3, 2005.

${ }^{2}$ Retired, former Provincial Forester for Ontario. E-mail: mamkaa@sympatico.ca
} 
Toronto, New Brunswick and Laval universities who would undertake the surveys.

3. The increasing activities of a pulp and paper industry, particularly in the spruce forests of eastern Canada.

Thus, between 1919 and 1951 there were many forest surveys undertaken by the federal Forestry Branch and in Ontario the Department of Lands and Forests and companies such as the Abitibi Power and Paper Co. Ltd., the Great Lakes Paper Co. Ltd., Longlac Pulp and Paper Co. Ltd., Marathon Paper Mills of Canada Ltd., Newaygo Timber Co. Ltd., Ontario-Minnesota Pulp and Paper Co. Ltd., and the Spruce Falls Power and Paper Co. Ltd. I mention these companies because their early efforts and reports together with those from federal and provincial forestry departments form a set of records which, to my knowledge, have not been fully utilized. The degree to which they have been preserved, if not maintained, and are available is highly variable. The lack of professional continuity in maintenance and availability of records in regeneration and other types of forest data reflect sadly on the profession and on those who own the forest.

Following World War II the Dominion Forest Service undertook a country-wide survey of cut-over and burned-over lands (Candy 1951). Interestingly, this survey resulted from a resolution of the Woodlands Section of the Canadian Pulp and Paper Association calling for data on regeneration on cutovers and rate of growth surveys and the formation of a joint committee from the forest industry, federal and provincial governments to bring about such a survey; notable was the absence of data for British Columbia. Generally, Candy concluded that reproduction was satisfactory east of the Great Lakes, but west of Lake Superior was much less abundant, but extent of sampling was very limited. For example, data for Ontario were based on two sites - one in the Mississagi River area and the other in the Clay Belt. Candy expressed doubt as to the value of the data given the limited sampling and noted that while the results are factual, interpretations and conclusions drawn from them may be controversial. If anything this study illustrates the dangers of attempting to determine regeneration on a regional, provincial or national scale using a single survey to satisfy the expressed need of a committee.

Hosie (1953), on behalf of the Research Council of Ontario, reviewed forest regeneration surveys conducted by federal and provincial organizations and companies in Ontario. A number of his observations and conclusions are, I believe, germane to the present discussion on regeneration. Early federal surveys used large plots - often 1 square rod $\left(272.25\right.$ sq. $\left.\mathrm{ft} .=25.3 \mathrm{~m}^{2}\right)$ - along a strip every two or five chains $(1$ chain $=66 \mathrm{ft} .=20.1 \mathrm{~m})$. Results were expressed in numbers of trees per unit area (no./acre), not in stocking . Ontario Lands and Forests surveys until just after the end of World War II used $1 / 20$ acre plots (2178 sq. $\mathrm{ft}$. $=202.3 \mathrm{~m}^{2}$ ). It was not until this period that the use of smaller plots - often $1 / 1000$ acre (milacre) — became common. The use of milacre plots has been related to the general planting on bare lands, as in southern Ontario, where a common spacing of 6 $\mathrm{ft}$. by $6 \mathrm{ft}$. allowing for some irregularity, resulted in approximately 1000 trees per acre, more or less uniformly distributed. Thus, it was reasoned that between $80 \%$ and $100 \%$ stocking using a milacre quadrat in cutovers would represent the type of stocking attained by planting. With the increasing use of the smaller plot sizes an emphasis was placed on stocking as opposed to density.

One of the difficulties with regeneration surveys that use different sizes of sample quadrats is in comparing results. This was a prime concern with Hosie, since the two most commonly used in Ontario post-1946 were one-thousandth and one six-hundredth of an acre. The larger the size of plot, the greater the chance of recording regeneration. This was recognized more than 20 years ago by the Alberta Forest Service - that increasing the size of plot automatically increased the percent values of stocking. To make valid comparisons of results from plots of different sizes, Grant (1951) compared results for plots of different sizes and developed a mathematical conversion to equivalents of a common size. His conclusions are pertinent to-day:

1. Never attempt to compare stocking figures unless they are based on the same size of quadrat or converted to equivalents of a common size of quadrat;

2. Be exceedingly wary of attaching an absolute significance to the stocking figure;

3. Realize that stands with the same stocking figure are not necessarily similarly stocked. Here he is referring to the effects of different densities of seedlings, and

4. Even in a relative sense, realize that stocking figures have some flexibility of significance.

I will not go into any discussion of sampling design - I leave that to the statisticians. I would note, however, that aside from the various rationales for single versus clustered plots there have been two developments in different types of surveys that have been used. The variable quadrat vertical transect survey developed by Bickerstaff (1961) proved to be a rapid means for obtaining data on extensive areas of old cutover lands prior to the establishment in Ontario of Forest Management Agreements in the 1980s. The use of sequential sampling (Dick 1963) provides an efficient means of undertaking surveys. In 1979, on behalf of the Ontario Ministry of Natural Resources a study (Clarke 1979) was commissioned to compare the various designs of survey utilizing different plot sizes. Clarke conducted the study on a variety of forest conditions from Ignace in the northwest to Cochrane in the east. He used single plots of four $(2 \times 2 \mathrm{~m}) \mathrm{m}^{2}$, eight $(2 \times 4 \mathrm{~m})$ $\mathrm{m}^{2}$ and $16(4 \times 4 \mathrm{~m}) \mathrm{m}^{2}$ in a systematic single plot design. For clustered plots he used single quadrats $(2 \times 2 \mathrm{~m})$ in combinations of two, four, and eight clusters to a total of 50 clusters. For the sequential trial the design of Dick was used with three sizes of plots, $4 \mathrm{~m}^{2}(2 \times 2 \mathrm{~m}), 8 \mathrm{~m}^{2}(4 \times 2 \mathrm{~m})$ and $16 \mathrm{~m}^{2}(4 \times$ $4 \mathrm{~m})$. He concluded that using the $2 \times 2 \mathrm{~m}$ plot, whether singly or in pairs, gave comparable estimates. There did not appear to be any advantage in using cluster sampling over single quadrats. Results from different-sized quadrats or cluster sizes showed they were not comparable, nor were those from variable density, i.e., as Grant (1951) had ascertained.

Generally, estimates of stocking increased with quadrat size. Density estimates were less sensitive to differences in quadrat size than stocking. The sequential sampling procedure showed an advantage over the other designs in reducing the amount of sampling necessary to obtain a reliable estimate of stocking, thus making field work more efficient.

Hosie's remarks about the use of stocking figures are also relevant. He noted the misuse of such data. For example, the 
equating of percent stocking to density as when based on $1 / 1000$ acre plots a stocking of $50 \%$ was interpreted as meaning there were at least 500 stems per acre. Stocking data are no more than indices of distribution and he suggested they should be referred to as "frequencies of occurrence." He noted the misuse of stocking percentages and incorrect reporting of reproduction has probably contributed more than anything else to disagreement regarding the nature of regeneration on cutover land. I would add that this is particularly true when these percentages are viewed by the public and media.

On the subject of stocking standards, Hosie's comments are again germane. He noted that in the federal Forestry Branch work, $80-100 \%$ was classed as "fully stocked," 60-79\% well stocked; $40-59 \%$ moderately stocked; $20-39 \%$ understocked; and less than $20 \%$ failure; other organizations have used similar categories. He raised the question - what is adequate stocking? The answer is, of course, it all depends; particularly on the relationship between the stocking at an early stage of development with future stand development and management objectives. He agreed that tentative standards will still have to be set but that doubt will remain regarding their reliability. It is the forest manager using present and past knowledge and experience that is in the best position to determine what those standards should be, not a provincial committee.

In this discussion of regeneration standards I have endeavoured to portray the evolution in Ontario of regeneration surveys and results. I think what occurred here is representative of other parts of the country. First, there is the scale or level at which concern is expressed as evidenced at regional and provincial levels on forests that have been cut-over or burned without any evidence of management. As surveys by companies and provinces became focused more on specific areas as in the 1930s and well after the 1940s, the standards used bore no relation to management objectives. What was needed were stand management objectives and the best available quantitative information on stand development over time as related to such measures as stocking at early ages of the stand. In 1978, Fred Robinson, the Boreal Silviculturist for the Ontario Ministry of Natural Resources, produced a set of standards. These were based on his review of standards being used in the field by government and company foresters. They were replaced with the introduction of Forest Management Agreements (FMAs) by standards related to each agreement area, developed jointly by local Ministry and company staff and documented in the Ground Rules and thus more clearly linked to specific objectives.

The development of regeneration surveys in North America has been one of evolution. The use of the quadrat as a sampling procedure was introduced by late $19^{\text {th }}$ century ecologists, and was not picked up by foresters until the 1920s. At that time, the U.S. Forest Service used 1/16 acre plots (as compared with $1 / 20$ acre plots used in Ontario), which were time-consuming and expensive to measure with results expressed in densities (numbers per acre). Lowdermilk in 1927 proposed using the quadrat system of the ecologists to measure what they termed "frequency index" of occurrence and which he proposed calling "stocking" expressed as a per cent. Haig (1929) compared the results from using quadrats in actual surveys where single plots were placed at intervals in contrast to strips of continuous plots. He found close agreement between the two for both frequency (stocking) and density (average numbers per acre). At this time the U.S. Forest Service was about to begin a nation-wide survey of forests, including regeneration. The Rocky Mountain Region of the Service had been exploring the use of one-milacre quadrats in surveys for some time according to Haig (1931) and 40\% stocking of regeneration would be considered in "excellent condition." On the basis of growth and development of western white pine (Pinus monticola Douglas. ex D. Don.), Haig recommended using a larger plot size (four-milacre). The milacre quadrat became a common plot size used in systematic line surveys, but as so often happens, developments in technology or knowledge in disciplines and subjects unrelated to forestry change the way we act. During World War II, Dr. A. Wald developed mathematically a concept for sequential sampling, although publication of his work was withheld by the United States government until 1947 (Wald 1947). Two Canadian foresters at the University of British Columbia, (Smith and Kerr 1958) were the first in this country to apply this sampling method at the UBC Forest at Haney. They used one-milacre plots and considered $40 \%$ stocking represented adequate reproduction for Douglas-fir (Pseudotsuga menziesii (Mirb.) Franco). They also made an important point: for foresters experienced in the local forest it is not difficult to identify the areas that are obviously satisfactorily or not satisfactorily regenerated. It is in the middle areas where results by observation may be questionable that surveys are required. The sequential sampling procedure of Dick (1963) is a useful survey method for such situations. In recent years, computers have been used to determine regeneration accuracies for different sampling methodologies (MacLeod 1977) or complex stands (Hassani et al. 2004).

The majority of forest lands in Canada are publicly owned and the general impact of harvesting has generally been perceived negatively, reflecting that, “...our forests are disappearing because trees are not being replaced as rapidly as they are being cut" (Hearnden et al. 1992). Governments, the forest industry and the profession have attempted rather unsuccessfully to counter such negativism by providing factual information about forests and forestry. Often the terminology used has been counterproductive. Such inventory terms as "barren and scattered" and "Not Satisfactorily Regenerated" have technical meanings quite dissimilar from what they mean to the lay person. The use of stocking percentages is another example. This is particularly true when professionals may determine that $40 \%$ is an acceptable minimum. I would suggest that the key concern for the public is that the forests and their values are being "preserved." One way to assure them they are being renewed is to present them with information that is accurate but presents a picture of the forest that is both understandable and perhaps imaginative and appealing to many of the public. Boyce (1995) suggested that there are three controls that are used to manage a forested landscape in attaining some specified sets of objectives. These are:

1. Rates of harvest;

2. Sizes of canopy openings, and

3. Kinds of regeneration.

Is it not possible to develop a way, based on the concept of these three controls, to provide the public with a meaningful 
and understandable "picture" of the state of their forests? In doing this, the picture must go beyond a simple statement of fact and create a mental vision of the forest. This is a challenge that foresters and governments representing the owners of public forest lands have yet to meet.

\section{References}

Bickerstaff, A. 1961. A variable quadrat regeneration survey method. For. Chron. 37(1): 39-54.

Boyce, S.G. 1995. Landscape Forestry. John Wiley \& Sons, New York. $239 \mathrm{p}$.

Candy, R.H. 1951. Reproduction of cut-over and burned-over land in Canada. Forest Research Division, Silvicultural Note No. 92. Forestry Branch, Department of Resources and Development, Ottawa. 224p. + maps.

Clarke, F.R. 1979. Comparison of regeneration survey designs utilizing various plot sizes. Typed mss. Ontario Ministry of Natural Resources, Toronto. 26 p.

Dick, J. 1963. Forest stocking determined by sequential stocked quadrat tally. Jour. For. (4): 290-294.

Fernow, E.B. 1902. Economics of Forestry. Crowell \& Company, New York.

Fernow, E.B., C.D.Howe and J.H. White. 1912. Forest Conditions of Nova Scotia. Commission of Conservation, Canada, Ottawa. 93 p. Grant, J.A.C. 1951. The relationship between stocking and size of quadrat. Faculty of Forestry Bull. No.1, University of Toronto Press, Toronto. $35 \mathrm{p}$.

Haig, I.T. 1929. Accuracy of quadrat sampling in studying forest reproduction in cut-over areas. Ecology 10(4): 374-381.
Haig, I.T. 1931. The stocked quadrat method in sampling reproduction in stands. Jour. For. 29: 747-749.

Hassani, B.T., V. LeMay, P.L. Marshall, H. Temesgen and AbdelAzim Zumrawi. 2004. Regeneration imputation models for complex stands of southeastern British Columbia. For. Chron 80(2): 271-278. Hearnden, K.W. S.V.Millson and W.C. Wilson. 1992. A report on the status of forest regeneration. Ontario Independent Forest Audit Committee. Ontario Ministry of Natural Resources, Sault Ste. Marie, Ontario. 117 p.

Hosie, R.C. 1953. Forest Regeneration in Ontario. Faculty of Forestry Bulletin No.2, University of Toronto Press, Toronto. 134 p. Howe, C.D. and White, J.H. 1913. Trent Watershed Survey: A Reconnaissance. Commission of Conservation Canada, Committee on Forests, Ottawa.

Lowdermilk, W.C. 1927. A method for rapid surveys of vegetation. Jour. For. 25: 181-185.

MacLeod, D. 1977. Accuracy of regeneration stocking estimates: tests with simulated data. For. Chron. 53(2): 77-81.

Robinson, F.C. 1978. Stocking standards for timber production. Ontario Ministry of Natural Resources, Toronto. unpublished manuscript.

Schlich, W. 1906. Manual of Forestry. $3^{\text {rd }}$ edition. Bradbury, Agnew \& Company Ltd., London.

Smith, J.H.G. and J.W. Kerr. 1958. Sequential sampling in reproduction surveys. Jour. For. 56: 107-109.

Wald, A. 1947. Sequential Analysis. Wiley \& Sons, Inc., New York. 